\title{
Analysis of Sharia Hotel Management in Bandung City in the Perspective of Maqashid Syari'ah
}

\author{
Enden Haetami \\ Sekolah Tinggi Agama Islam YAPATA Al-Jawami Bandung, Indonesia \\ Email: endenhaetami@yahoo.com
}

\begin{abstract}
This study aims to analyze the management of Sharia hotels in the city of Bandung from the perspective of Maqashid Syari'ah. This research uses qualitative research with a descriptive analysis approach. The data in this study are primary data and secondary data. Methods of data collection in this study are through observation, in-depth interviews, and literature study. This object needs to be studied to find out the ideal Islamic muamalah in the hotel business labeled shari'ah. The population in this study were all hotels marked shari'ah in the city of Bandung. At the same time, the sample in this study is Noor Hotel which is considered a good representation of information and management. With the reflection of Maqasid Al-Syariah, it is hoped that sharia brands can positively influence the sharia-based muamalah format in Indonesia. Based on the research analysis results, it can be concluded that: 1) Material Characteristics, by applying according to Islamic law, namely by checking the identity of visitors carefully and the message service facilities are not the same as Conventional Hotels. The implementation of the sharia management system at the Syariah Hotel Noor Bandung has similarities and differences with other hotels; and 2) Immaterial Characteristics, namely by referring to Maqashid-Shari'ah values, such as Amar Ma'ruf Nahi Munkar, the principle of upholding the truth, the focus of supporting justice, the principle of Latuzlimuna wala Tuzlamuna, the principle of trust, and the principle of benefiting the ummah.
\end{abstract}

Keywords: Analysis, Management, Sharia Hotel, Maqashid Syari'ah.

\section{A. INTRODUCTION}

In this era, business development in Indonesia in the hospitality sector is increasing. And in every province or city, there are jasmine hotels to five-star hotels. Businesses in this field are increasingly in demand because they can develop anywhere in big and small towns (Ala'uddin, 2021).

The biggest challenge faced by Muslims at this time is the alignment of Islamic ideology with the various dimensions of life faced by humans, for example, Islamic ideology with education, Islamic ideology with social and also Islamic ideology with other things that are often faced by humans, whether it is macro or micro (Alserhan et al., 2018). Through their religious ideology, Muslims are challenged to be able to answer various problems of the world community. One big thing that Muslims must answer and find a solution for is the backwardness of Muslims in the economic field (Habibah, 2020). In terms of economy, if Muslims are compared to the western world, it can be said that Muslims are still inferior to them. Whereas in Islam itself, the economy is a priority to be developed.

Efforts to match or exceed the Western world economy by implementing the Western world economic development model are not guaranteed success if applied 
in the Muslim world (Hall \& Prayag, 2019). This is due to differences in cultures, values, views of life, and different ideologies. The theory and development model developed in the West is strongly influenced by the values of secularism, liberalism, and capitalism embraced by most Western societies. Meanwhile, the Muslim world makes religion the primary variable in economic development (Hasyim \& Fauzi, 2019). However, there may be similarities in the development model between what is applied in the Western world and the Muslim world as long as it does not conflict with the main goals of Islamic teachings (Maqashid Shari'ah).

The development of the Islamic economic system in Indonesia has been very rapid in recent years; this development is felt when observing the emergence of Islamic financial institutions after the enactment of Law Number 21 of 2010. The result of Islamic financial institutions has become a milestone in developing Islamic economics in Indonesia (Karia \& Fauzi, 2019). As one of the Islamic economic system instruments, Islamic financial institutions have shown different behavior and specific products from the mainstream activities of other financial institutions that apply in Indonesia. These developments cannot be separated from the attention and support of the government in building specific regulatory instruments, thus giving complete confidence to investors to embed their model in this sharia-based financial institution (Karim et al., 2017).

The Islamic economic system is now entering the second stage, namely the system development stage, where the direction is to develop other instruments (besides finance). Currently, in society, several Islamic economic institutions have emerged, such as pawning, insurance, capital markets, and sharia hotels (Mahamood et al., 2018). Some of these institutions that have received a response from the government and the arrangements that have been set are insurance, capital markets (Masyhadi, 2018). In contrast to these Islamic financial institutions, sharia hotels which are currently spreading in several areas of the country, have not received sufficient attention, especially on the regulatory and regulatory aspects of the authorized institutions, especially the National Sharia Council-Indonesian Ulema Council (Majelis Ulama Indonesia) within the framework of sharia standardization.

As one of the world's tourist destinations, the attractiveness of Indonesia's tourist attractions fascinates travelers from various parts of the world. The tourism industry in the country has had a significant impact on the community's economic development, especially with the growing development of tourism supporting industries, namely the accommodation sector and other creative industries (Muda et al., 2020). The accommodation sector is one of the indicators of the development of the tourism industry in Indonesia. Various hotel classes have sprung up in major tourist destinations, both from hotels with star and non-star qualifications (Priyadi \& Pambekti, 2019).

Sharia hotels have recently participated in making a reasonably positive contribution to the tourism industry in Indonesia. In several areas, such as Medan, Kendari, Bandung, Surabaya, Semarang, Yogyakarta, and Jakarta, star-class sharia 
hotels have shown quite good development. Several non-star class hotels and guest houses that also use sharia principles spread throughout Indonesia with quite significant segments and enthusiasts. (Rahman et al., 2017). The word business in the Qur'an is Al-tijarah which means trade or trade. At-tijaratun Walmutjar, namely marketing, commerce (according to the Al-Munawwir dictionary). According to ArRaghib Al-Asfahani in Al-mufradat fi Gharib Al-Qur'an, at-tijarah means managing property for profit in business.

Three essential and ethical principles must be applied in sharia business: 1) Tawhid (unity), leading humans to the recognition of the oneness of Allah as the Lord of the Universe. In its womb, it believes that everything that exists in nature originates and ends in Him; 2) Balance or Equilibrium is a concept that shows the existence of Social Justice; and 3) Free will, that is, humans have the potential to make various choices because human freedom is not limited (Rahmiati \& Fajarsari, 2020). But in the free will that God has given to humans, it must be in line with the basic principles of human creation, namely as caliphs on earth. Thus, free will must be in line with the benefit of individual interests, especially in the people's interests (Renie et al., 2019).

In Arabic, the term economics is expressed by al-iqtisad, which means simplicity and frugality. Based on this meaning, the word al-iqtisad develops and expands to contain the essence of ilm al-iqtisad, namely science related to economics. In this case, Ali Anwar Yusuf defines economics as the study of human behavior concerning the utilization of scarce productive resources to produce goods and services and distribute them (Rusydiana et al., 2021).

It has become Sunatullah that every human being lives in an activity mentioned in the economic sense discussed above. Without cooperation, humans can't normally live (Salleh et al., 2019). Association has an element of taking and give, helping and being assisted. One of the essential aspects of conducting cooperation is in muamalah, namely trading activities, leasing, debts, and so on (Sen Kupeli et al., 2018). This activity absorbs $85 \%$ of the existing workforce. In the perspective of Islamic law, this, of course, must meet the standard or paradigm of Maqashid Syariah as support for Islamic economic development.

Based on Ahmad Masyhadi's (2018) research, an Islamic economic system that places the fulfillment of basic needs as a top priority to maintain five main benefits, namely the maintenance of religion, soul, mind, descendants, and property. Every individual has the right to fulfill his basic needs to maintain life and carry out his leading role as Khalifah on earth. On the other hand, from an Islamic perspective, economic development places humans as the center of the action, acting as a subject and an object of evolution itself (Zahara, 2020). This is based on the Islamic worldview that places humans as the main actors in human life.

Nowadays, in Indonesia itself, the formulation of every Islamic financial product comes from the study of ushul figh and maqashid sharia. Academics and practitioners of Islamic economics, it is not enough to know the products of muamalah figh and the application of financial products. Still, it must understand the 
methodology of istimbath, and ijtihad ulama in formulating and determining a problem of Islamic law, especially on policies, systems, mechanisms, and products,

For example, the rise of sharia-labeled hotels in Bandung has become a new trend in the accommodation business. Some of them have become icons of Islamic Da'wah for planning who want to feel the serenity of sharia hotel facilities when they stop in the city of Bandung. Travelers feel their own inner experience when they are guests of five-star hotels according to the sharia concept. This phenomenon is also an indicator that the hotel business in Indonesia is still in a dire state because it is often in the news published in the mass media about negative things about hospitality in Indonesia, especially in big cities (Zatadini \& Syamsuri, 2018).

To answer this, the accommodation market players create a hotel concept that is labeled sharia. Because of the existence of this hotel, it is now suspected to be one of the hotel models that offer facilities that follow sharia values. Because the rules of this hotel are stringent in enforcing the conditions for guests who want to visit and stay, in other words, the public will automatically think again if they do things that are not right and violate sharia. In addition, what is more, interesting about this sharia hotel is that it is designed to improve a person's moral quality and character. This can be seen from the Maqashid Sharia values (sharia goals) that this hotel carries. The purpose of this sharia is nothing but to provide value for the benefit of the wider community. In addition, the development of sharia hotels is considered a tourism supporter that is commercially oriented and always upholds the noble values of religion and customs of a nation.

\section{B. METHOD}

This research uses qualitative research with a descriptive analysis approach. The data in this study are primary data and secondary data. Methods of data collection in this study are through observation, in-depth interviews, and literature study. This object needs to be studied to find out the ideal Islamic muamalah in the hotel business labeled shari'ah. The population in this study were all hotels marked shari'ah in the city of Bandung. At the same time, the sample in this study is Noor Hotel which is considered a good representation of information and management. With the reflection of maqasid al-syariah, it is hoped that the sharia brand can positively influence the sharia-based muamalah format in Indonesia.

\section{RESULT AND DISCUSSION}

\section{Concept and Management System of Noor Syari'ah Hotel Bandung}

Noor hotel is located on Jalan Madura Number 6, Jalan Riau Bandung, West Java Province. With a unique concept such as the Middle East, which is very good as a photo spot, this hotel is one of the sharia hotels that is a destination for travelers from various regions who stop in the city of Bandung. Noor hotel also pays attention to the comfort of visitors who want to worship with complete worship equipment. In addition, other facilities found in this hotel are meeting rooms, 
restaurants, and airport and station transfers. The hotel instills solid Islamic values in its interior design and business management.

The management mentions the vision, mission, and motto as the value base. According to the administration, these values are not just a trend but a way of life motivation that can ground the concepts and management systems in a syar' $i$ form. Then the management also uses a concept and management system according to sharia. This concept is the final price because, according to the hotel manager from the beginning, the founders wanted the sharia brand to strengthen their hearts. According to him, sharia principles make Hotel Noor Syariah Bandung different from conventional hotels. Buildings that are motivated by sharia norms make their operations run according to sharia so that their establishment is not just a business emotion but based on sharia motivation to strengthen the righteousness of the founders.

As explained above, the concept and management system of Hotel Syariah Noor Bandung can be seen through its vision, mission, and motto. Because from here, the values of the concept and the basis of an existing management system will be found. According to the manager, the concept and management system of Hotel Syariah Noor Bandung is guided by two aspects: The first is based on the sharia principles of muamalah, and the second is based on the sharia management function system. In sharia principles, Islamic muamalah provides the following concepts:

The principle of Amar Ma'ruf Nahi Munkar. This principle means inviting, doing good deeds, namely excellent and commendable actions such as helping ( $\left.t a^{\prime} a w u n\right)$ (Surah Al-Maidah [5]: 3). Give each other good advice, uphold justice, improve welfare, and so on. At the same time, nahi Munkar means preventing evil deeds, preventing destructive actions for themselves and others (Surah Annisa [4]: 29). This concept for Muslims is mandatory because it is in line with the commands of the Qur'an and al-Sunnah.

The Principle of Enforcement of Truth. This means that Islam is a divine method to uphold the truth and at the same time eliminate falsehood. The goal is to create a just, prosperous society that is pleasing to God. The concept of upholding the truth is measured according to the norms of Islamic teachings.

Principles of Enforcement of Justice. Islamic law requires people to be fair, whenever and wherever. While still enjoying this life, whoever the person is must act pretty because it is ordered by Allah Almighty (Surah Annisa '4: 29). Fair here does not recognize happy or complex conditions. The principle of justice does not look at what and who is a person's status in obtaining his rights as a human being born according to his nature. Therefore, partially upholding justice is not appropriate.

The principle of La Tazhimun wala Tuzhlamun. In Islamic muamalah, there is a principle that all actions as long as the law is permissible unless there is evidence from the Qur'an and Hadith that forbids it. In sharia hotel services, the principle of la tazhimun wala tuzhlamun becomes the guideline (QS. Al- 
Baqarah [2]: 272). This text aligns with human nature to protect each other and keep each other away from damage. As a relatively new Islamic service, this principle's role is needed to interpret religious teachings in terms of muamalah. The deepening of this principle will be a consequence of the birth of falah in the world so that management runs according to sharia. In line with sharia branding, of course, it is unethical if this principle is neglected. The focus of la tazlimuna wala tuzlamun is logical because services based on sharia run with muamalah rules. The consideration will remain to avoid forbidden muamalah transactions.

Trust Principle. This principle is to carry out the trust of someone to carry out their duties and obligations. A person feels burdened if, in this principle, he is not motivated by anything in his life. And it is impossible to succeed if this principle is ignored. Therefore, the Qur'an invites Muslims to carry out their mandate (Surah Al-Maidah [5]: 1). And the purpose of the principle of trust is nothing but a reminder for humans to escape the torment of hellfire (Surah Atthalaq [65]: 12).

The Principle of the Benefit of the Ummah. The following principle in the management system of Hotel Syariah Noor Bandung City is the benefit of the ummah. Malahat implies that this principle is in line with the concept of maqasid al-Sharia Imam al-Syatibi. That is a principle in the context of muamalah by not leaving Maqasid Al-Khaimah. In this concept, the basis is to uphold the welfare of consumers accordingly. This welfare includes the maintenance and improvement of the quality of life of its elements, namely religion, soul, mind, lineage, and property.

\section{Maslahah Concept in Muslim Consumer Perception}

To realize the benefit in the world and the hereafter, there are five main elements, namely: a) Religion; b) Soul; c) Intellect; d) Descendants; and e) property. The explanation of these five things is presented in the following table:

Table 1. Five Maslahah in Maqashid Shari'ah

\begin{tabular}{|l|l|}
\hline Maslahah Elements & \multicolumn{1}{|c|}{ Explanation } \\
\hline & $\begin{array}{l}\text { Humans need religion. There is no point in living; even } \\
\text { religion is the most important of all basic needs. To } \\
\text { protect the honor of faith, the Shari'a prescribes severe } \\
\text { punishments for religious crimes. Religion ranks first } \\
\text { because all the teachings of the Shari'a direct humans to } \\
\text { act according to His will and the pleasure of God. } \\
\text { Therefore, in the Qur'an \& Hadith, humans are } \\
\text { encouraged to believe in Allah, and this is the foundation } \\
\text { of Islamic economics in particular. The economic } \\
\text { relationship with this aspect of aqidah allows economic } \\
\text { activity in Islam to become worship. }\end{array}$ \\
\hline
\end{tabular}




\begin{tabular}{|c|c|}
\hline Hindu al-Nafs & $\begin{array}{l}\text { Caring for the soul is meant to maintain the right to live } \\
\text { in honor and protect the soul from avoiding acts of } \\
\text { persecution in killing, cutting off limbs, or injuring, } \\
\text { including consuming foods that can damage the body or } \\
\text { excessive consumption (israf). }\end{array}$ \\
\hline Hindu al-Aql & $\begin{array}{l}\text { Shari'a views the human mind as a significant gift from } \\
\text { Allah. The human mind can distinguish what is good and } \\
\text { evil with the human mind assigned to worship God. An } \\
\text { unreasonable person is not burdened with the duties of } \\
\text { the Shari'a. Therefore reason must be preserved and } \\
\text { protected. For this reason, the Shari'a forbids alcohol and } \\
\text { everything that can kill the creativity of reason and the } \\
\text { passion of human work. So that in Islamic economics, } \\
\text { alcohol and the like are seen as having no value starting } \\
\text { from producing, distributing, to consuming. }\end{array}$ \\
\hline Hindu al-Nal & $\begin{array}{l}\text { Worldly and God intends hereafter benefits to be } \\
\text { continuous from one generation to another. Shari'a that is } \\
\text { implemented in one generation alone is meaningless due } \\
\text { to the extinction of the human generation. For this reason, } \\
\text { Islam regulates marriage and forbids adultery, } \\
\text { determines who may be married, how marriage } \\
\text { procedures and the conditions and pillars must be met. } \\
\text { All of them are a form of preserving healthy and clean } \\
\text { offspring in a calm and peaceful atmosphere. Thus, it will } \\
\text { be more numerous and more substantial and create unity } \\
\text { and integrity in the community in which they live. In this } \\
\text { context, the sanction of flogging and stoning for } \\
\text { adulterers and other ta'zir punishments protects } \\
\text { offspring. }\end{array}$ \\
\hline Hifdzu al-Maal & $\begin{array}{l}\text { Although, in essence, all property belongs to Allah SWT, } \\
\text { Islam recognizes a person's rights. Islam requires } \\
\text { regulations regarding muamalat such as buying and } \\
\text { selling, renting, borrowing, pawning, and so on, and } \\
\text { prohibiting fraud and the practice of usury. Maintaining a } \\
\text { property is also understood by regulating the muamalat } \\
\text { system based on justice and willingness, trying to develop } \\
\text { wealth, and handing it into the hands of people who can } \\
\text { maintain it properly because the assets that are in the } \\
\text { hands of individuals become a strength for the people as } \\
\text { a whole as long as they are appropriately channeled. }\end{array}$ \\
\hline
\end{tabular}

Source: Processed Data 
There are two forms of Muslim consumer thinking concepts that are present in the financial world today. The first concept is utility, current in conventional science. The concept of utility is defined as the concept of consumer satisfaction in the consumption of goods or services. The second concept is that mashlahah is defined as mapping consumer behavior based on needs and priorities; it is very different from the utility that has unlimited plural mapping.

These two concepts are different because each different epistemology forms them. Thus, consumer behavior is integrated with rationalism, and religious norms are deliberately set aside. Meanwhile, maslahah was born from Islamic epistemology. The motivation of the concept of mashlahah is similar to that of the Smithian to achieve natural freedom. However, in Islam, selfactualization and the role of humans to attain genuine freedom are not entirely controlled by the laws of human ratio but are owned by religious treatises.

The thrifty attitude, limiting oneself to halal goods, and prioritizing basic needs are not found in the concept of utility but only in mashlahah. This shows that it seems complicated to find common ground between the two concepts. The differences can be described as follows: (1) The concept of utility forms the perception of materialistic satisfaction while mashlahah forms the perception of human needs; (2) The concept of utility affects the perception of consumer desires while mashlahah forms the perception of rejection of harm; (3) The concept of utility reflects the role of self-interest while mashlahah manifests individual perceptions about the efforts of each charity movement mardhatillah; and (4) the concept of utility; the perception of desire has the aim of achieving materialistic satisfaction while mashlahah; Mardhatillah's efforts encourage the formation of perceptions of Islamic needs.

Maslahah theory is an integration of thinking and remembrance. He describes the motive of individual simplicity in every form of consumer decision. In this case, because mashlahah aims to give birth to benefits, perceptions are determined according to need. The concept of mashlahah is not in harmony with harm, which is why it gives birth to the perception of rejecting harm such as forbidden goods, including syubhat, a form of consumption that ignores others and endangers oneself.

\section{Implementation of the Concept and Management of Sharia Hotel Noor Bandung}

Hotel Management Syariah Noor Bandung uses the principles of sharia muamalah as a guideline and uses the sharia management function as a guide in its management system. The exploration of the application of the concept and management system of Hotel Syariah Noor Bandung is described as follows:

The principle of Amar Ma'ruf Nahi Munkar. The context of the application of Amar Ma'ruf Nahi Munkar in the management of Hotel Syariah Noor Bandung is carried out such as prohibiting visitors who are not married 
couples. Even though they have a clear identity, such as an ID card and an exact address, they will be banned from entering if the marriage record is not proven. Based on experience, identities such as Identity Cards (KTP) for visitors are asked to show. Here the management will look at it carefully. Then the status is questioned, whether it is faithful husband and wife or not. And if the identity card does not match, the identity will be checked with a good marriage book. According to the management, this step is to anticipate things that are not desirable and can be contrary to sharia principles.

The Principle of Enforcement of Truth. The context in applying this principle includes that visitors are prohibited from bringing dangerous objects that can disrupt public order. It aims to create a safe and comfortable environment for visitors and hotel guests. The application of this principle is the task of the management in carrying out the teachings of Islam. Upholding the truth aims to create a just, prosperous society that is pleasing to God. The other side of applying this principle is that the management provides ideal facilities for visitors, such as places of worship.

Principles of Enforcement of Justice. The application of this principle is in the form of equal treatment between Muslim and non-Muslim visitors. For non-Muslims, when entering the Noor Bandung Syariah Hotel, are not allowed to do anything or bring anything that violates Islamic law. Like bringing alcoholic drinks, bringing women who are not legal. That also applies to Muslim visitors. There is no tolerance for any visitors who have crossed the sharia provisions. Sharia provisions apply to any visitor, and if there is a strong objection, the management can force it. In addition to keeping Sharia hotels away from moral damage, the comfort and tranquility of the hotel are maintained.

The principle of La Tazhimun wala Tuzhlamun. The principle of la tazhlimun wala tuzhlamun views that in muamalah, it is known that it cannot be wronged and cannot be wronged. The point is to save managers and consumers from damage. Various facilities with variants certainly invite lust, but in Hotel Syariah Noor Bandung, facilities are prioritized for consumers without disturbing health and comfort. The implementation of this principle has taken care of the consequences so that management runs according to sharia. Therefore, the benefits of facilities in terms of comfort and safety for visitors are adequately considered. The application in this principle is that the management avoids completely all muamalah transactions, which are prohibited according to Islamic law. In other applications, Hotel Syariah Noor Bandung provides food that has halal clarity and has useful functions. This is realized by delivering cafes or Islamic cuisine with "Thayyibah" by offering $100 \%$ halal food and drinks.

Trust Principle. This principle is in the form of the implementation of management that is carried out responsibly. Like most companies, the management always gives periodic warnings to staff and employees to carry out their mandate. All team receives notifications if they are negligent in their 
duties. The administration does not hesitate to give firmness and provide sanctions if there is a violation. All Sharia Hotel staff are taught politeness.

Benefit Principle. Applying the principle of benefit implies that this principle is in line with the concept of Maqasid Al-Syariah. The application of this principle is the basis for upholding the welfare of consumers, according to sharia. This welfare includes the physical maintenance of visitors to the elements of religion, soul, mind, lineage, and property. One example of this principle is the management's efforts to satisfy consumers by providing healthy (good) and halal value food. The method is adjusted according to his needs. With these efforts, there will be a harmonious relationship between the service and the consumer to fulfill the benefits. Muamalah transactions used in the management of Hotel Syariah Noor Bandung consist of various spiritual values such as honesty, transparency, morality, and ethics that the hotel still uses to attract visitors.

It is essential to trace the implementation of this approach to obtain a form of syar'i format that can genuinely implement Islamic teachings. At least it can be formulated into the following aspects: 1) Service aspect, an officer must be able to carry out the mandate and provide services following Islamic principles. Service gives importance to the essence of neat management; 2) Facilities aspect, in this aspect the existing facilities are expected to meet consumer needs. The needs prescribed for consumers certainly do not conflict with the principles and values of the rules of Islamic law; 3) The benefits aspect, this third aspect in terms of business is often contrary to the Shari'a, but there are still many consumers violate it. Like alcoholic beverages in various conventional hotels, it is unavoidable. The format of sharia management in the aspect of benefits is not negotiable. For this reason, everything that negates the benefits of Islam must be prohibited; and 4) Aspects of objectives, aspects of dreams as an effort to implement syar'i facilities must be selected in advance such as identity checks for visitors, provision of useful tools, and so on.

To create a sharia market format, the function of the management system is carried out correctly. This is a means for an organization to run well. If the system's operation has been running periodically, then the results will be picked because the running of the system indicates the life of institutional management. The organizational process must carry out the planning function as a company construction. The executive function may be controlled or supervised by an "Internal Independent Body," while the actuating process is an internal part of the organization that provides orientations.

The structure of the management function has a hierarchy. Based on the level, the division of the management hierarchy is as follows: (1) Top Management; (2) Middle Management; (3) Supervisory Management; (4) Lower management; and (5) Operative management. Hotel Syariah Noor Bandung, as a sample of sharia management structuring, has managed parallel to conventional hotels. With the vision and mission capital, the management system is carried out ethically. As stated above, Hotel Syariah Noor Bandung has been mandated to manage productive waqf. 
The central religious department feels that it supports the development of productive waqf as a sample form of sharia management structuring. In other words, the structuring of sharia management is under the umbrella of state institutions (Ministry of Religion) in realizing sharia-based economic potentials. If the trade sector is developed based on sharia principles, then it will bring mutual benefit on a macro basis. It even has excellent help in the process of development and economic growth.

Then the second reference is to place the basis for a performance policy that supports the fundamental values. The cause is the abolition of usury, the implementation of lost and profit-sharing, the institutionalization of zakat, and the prohibition of israf (QS. Al-An'am [6]: 30).

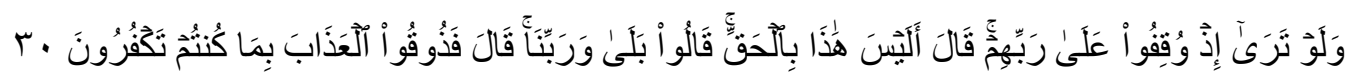

30. And could you see when they are made to stand before their Lord. He will say: Is not this the truth? They will say Yea! by our Lord. He will say: Taste then the chastisement because you disbelieved.

The above management functions cannot be separated from one part to another, which is an organization. These functions are interrelated with each other. The management function cannot be separated from the elements of planning, organizing, directing, and being equipped with adequate supervision. After sketching the management functions, then a performance structure is made so that management runs well. The performance structure is made in the framework of functioning management towards a point of success or victory.

In addition, marketing and sales are crucial points in business success. Sharia recommends that in the marketing of products and services, there are no elements that can harm others, such as fraud, for example, 1) Ihtikhar, namely hoarding goods to get high profits; 2) Gharar, namely obscurity; 3) Contains elements of usury: 4) Transactions carried out must be based on consensual (Antaradhin) which will not cause disputes; 5) Have Social Responsibility. In financial management, Hotel Syariah Noor Bandung uses the services of Islamic banks in all economic, insurance, and banking matters. The operation of a sharia hotel must be supported by the hotel's Articles of Association/Household as a sharia hotel.

The existence of Islamic financial institutions in Indonesia is a blessing. Since following the banking regulations in 1992 until now, it still exists and can show significant opportunities for developing the Islamic economy in Indonesia. Its role is not tiny in efforts to implement the economy through the syar'i path. In applying this sharia management standardization, there are at least two sources used as references. The first place the fundamental values of Islamic economics as a policy for muamalah activities, and the second establishes the basis for a performance policy that supports these actual values.

Regarding the fundamental economic values, Islam has given a set of values that have been believed with all faith. It will become the paradigm of Islamic 
economics so that muamalah is following the will of Sharia. These fundamental values (Both philosophical, instrumental, and institutional values) are based on the Qur'an and Sunnah, which are the highest sources of teachings in Islam. While in conventional economics, it has no basis because it comes from human scientific engineering. However, to obtain these fundamental values, a set of tools is needed to analyze so that axioms apply to social rules and economic behavior. There are three underlying Islamic economic values, namely: (1) monotheism, (2) justice, and (3) freedom and responsibility. However, several experts differ in formulating the fundamental values for Islamic economics, including Syed Nawab Haidar Naqvi, who gives four actual values: 1) Unity or monotheism, 2) Equilibrium or justice, 3) free will, and 4). Accountability.

\section{CONCLUSION}

Based on the results of research analysis, it can be concluded that the application of management with the Maqasid Syari'ah approach at Hotel Syariah Noor Bandung has two strong characteristics, namely: 1) Material Characteristics, by applying according to Islamic law, namely by checking visitor identities carefully and message facilities. The service is not the same as conventional hotels. Using the sharia management system at the Syariah Hotel Noor Bandung has similarities and differences with other hotels. Among the similarities in managing as generally other companies implement management functions; and 2) Immaterial characteristics, which are guided by Maqashid-Shari'ah values, such as Amar Ma'ruf Nahi Munkar, the principle of upholding the truth, the focus of supporting justice, the principle of latuzlimuna wala tuzlamuna, the principle of trust, the direction of the benefit of the ummah, and the sharia management system.

\section{REFERENCES}

1. Ala'uddin, M. (2021). Nilai Filosofis Maqashid Syariah dalam Ekonomi Islam. Jurnal Qiema (Qomaruddin Islamic Economics Magazine), 7(1), 68-80.

2. Alserhan, B. A., Wood, B. P., Rutter, R., Halkias, D., Terzi, H., \& Al Serhan, O. (2018). The transparency of Islamic hotels: "Nice Islam" and the "self-orientalizing" of Muslims?. International Journal of Tourism Research, 20(4), 475-487.

3. Habibah, M. (2020). Implementasi Maqashid Syariah Dalam Merumuskan Tujuan Laporan Keuangan Bank Syariah. AKTSAR: Jurnal Akuntansi Syariah, 3(2), 177-92.

4. Hall, C. M., \& Prayag, G. (Eds.). (2019). The Routledge handbook of halal hospitality and Islamic tourism. Routledge.

5. Hashim, N. I., \& Fauzi, N. M. (2019). The Concept of Shariah Compliant Hotel Business in Malaysia. Online Journal of Research in Islamic Studies, 6, 73-78.

6. Hashim, N. I., \& Fauzi, N. M. (2020). Investigating the Operational Issues of Islamic Hotel Business in Malaysia: A Conceptual Paper. Journal of Islamic Philanthropy E Social Finance (JIPSF), 1, 1. 
7. Karia, N., \& Fauzi, F. A. (2019). Explaining the Competitive Advantage of Islamic Hotel Concepts: Insights from Malaysia. In The Routledge handbook of halal hospitality and Islamic tourism (pp. 83-92). Routledge.

8. Karim, M. H. A., Ahmad, R., \& Zainol, N. A. (2017). Length of working experience as a moderator in a hotel managers' behavioral intention to adopt Islamic quality standards for hotels in peninsular Malaysia. Journal of Global Business and Social Entrepreneurship, 1(3), 133-151.

9. Mahamood, S. F., Fikri, A., \& Nor, N. S. N. M. (2018). Modeling Grand Blue Wave Hotel in Managing Challenges of Islamic Hotel Performance (IHP): An Overview of the Islamic Spirituality Instilled. In Proceedings of the 3rd International Halal Conference (INHAC 2016) (pp. 283-289). Springer, Singapore.

10. Masyhadi, A. (2018). Maqashid Syariah Sebagai Paradigma Pengembangunan Ekonomi Islam. Al-Musthofa: Journal of Sharia Economics, 1(2), 54-63.

11. Musa, A., Abd Gadhas, Z. A., Kadir, S. A., Din, N. M., Zakaria, M. N., \& Yajid, A. A. (2020). An Emergent of Islamic Tourism and Hotel: A Readiness, Opportunity, and Obstacle to be Solved; an analysis of Hoteliers' Perspective.

12. Priyadi, U., \& Pambekti, G. T. (2019, April). The Implementation Potential of Village Fund in Islamic Economic Perspective with the Instrument of Maqashid Syariah. In 3rd Annual International Seminar and Conference on Global Issues (ISCoGI 2017) (pp. 184-188). Atlantis Press.

13. Rahman, F. K., Tareq, M. A., Yunanda, R. A., \& Mahdzir, A. (2017). Maqashid AlShari'ah-based Performance Measurement for the Halal Industry. Humanomics.

14. Rahmiati, F., \& Fajarsari, A. R. (2020). The Role of Religiosity Mediating Islamic Attributes on Tourist Preference At Sharia-Compliance Hotel. Jurnal Muara Ilmu Ekonomi dan Bisnis, 4(1), 54-63.

15. Renie, E., Luth, T., \& Hamidah, S. (2019). The Maslahah Concept in the Islamic Finance Institutions. JL Poly $\mathcal{E}$ Globalization, 87, 117.

16. Rusydiana Mr, A. S., Hasib, F. F., \& Rahayu, S. S. (2021). Islamic Hotel Indicators: A Bibliometric Study. International Journal of Religious Tourism and Pilgrimage, 9(1), 13.

17. Salleh, N. Z. M., Hamid, A. B. A., \& Hashim, N. H. (2019). Positioning Islamic hotel tourism: A new perspective. Partridge Publishing Singapore.

18. Salleh, N. Z. M., Nor, R. M., Selamat, R., Baharun, R., Abdullah, D. F., \& Omain, S. Z. (2019). Challenges in implementing Islamic friendly hotel in Malaysia. Journal of Economic Info, 6(4), 15-17.

19. Şen Küpeli, T., Koc, B., \& Hassan, A. (2018). Understanding religion-based tourism terminology in the context of the hotel industry. Anatolia, 29(2), 252-266.

20. Zahara, F. (2020). The Analysis of Maqashid Syariah on the Use of Fiat Money and Dinar Dirham. Budapest International Research and Critics Institute (BIRCIJournal): Humanities and Social Sciences, 3(2), 1216-1226.

21. Zatadini, N., \& Syamsuri, S. (2018). Konsep Maqashid Syariah Menurut AlSyatibi dan Kontribusinya dalam Kebijakan Fiskal. Al-Falah: Journal of Islamic Economics, 3(2), 1-16. 